\title{
ANALISIS HUBUNGAN KETERAMPILAN MEMBACA DENGAN KETERAMPILAN MENULIS SISWA SEKOLAH DASAR
}

\author{
Agustin Rinawati $^{1)}$, Lilik Binti Mirnawati $\left.{ }^{2}\right)^{*}$, Fajar Setiawan $^{3)}$ \\ 1,2,3) Universitas Muhammadiyah Surabaya \\ agustin.rinawati-2016@fkip.um-surabaya.ac.id'1 , lilikbintimirnawati@fkip.um-surabaya.ac.id², \\ fajarsetiawan@ @ fip.um-surabaya.ac.id ${ }^{3}$ \\ *penulis korespondensi
}

\begin{abstract}
ABSTRAK: Tujuan dalam penelitian ini adalah untuk mengetahui hubungan antara keterampilan membaca dengan keterampilan menulis siswa sekolah dasar. Hubungan tersebut dapat dilihat dari hasil analisis data dari beberapa jurnal dan buku. Penelitian ini diawali dengan merumuskan permasalahan kemudian mencari data dari jurnal dan buku yang relevan. Penelitian ini menggunakan jenis penelitian kualitatif dengan metode studi literatur dengan menggunakan data sekunder yang berasal dari 10 jurnal yang telah dianalisis sebelumnya. Berdasarkan analisis yang telah dilakukan hasil penelitian menunjukkan bahwa ada hubungan positif yang signifikan antara keterampilan membaca dengan keterampilan menulis narasi pada siswa sekolah dasar. Rata-rata yang didapatkan untuk keterampilan membaca sebesar 54,65\% sedangkan untuk keterampilan menulis sebesar 55,14\%. Dapat disimpulkan bahwa keterampilan membaca dan menulis memiliki hubungan yang sangat erat, semakin banyak dan baik dalam membaca maka karya tertulisnya juga semakin baik. Berdasarkan hasil analisis dalam penelitian ini maka diharapkan siswa memiliki keterampilan membaca yang baik karena dengan membaca sangat berpengaruh terhadap keterampilan menulis yang dimiliki. Penelitian ini juga dapat digunakan sebagai saran untuk guru agar dapat memotivasi dan memperhatikan siswanya dalam keterampilan membaca dan menulis dan sebagai rujukan bagi peneliti lain, karena hasil penelitian ini didapatkan dari analisis dari 10 jurnal yang telah terakreditasi dan sesuai dengan variabel yang diambil.
\end{abstract}

Kata kunci: Keterampilan Membaca, Keterampilan Menulis Narasi

ABSTRACT: The purpose of this study was to determine the relationship between reading and writing skills of elementary school students. The relationship can be seen from the results of data analysis from several journals and books. This research begins with formulating the problem then looking for data from relevant journals and books. This research uses qualitative research with literature study methods using secondary data from 10 journals that have been analyzed previously. Based on the analysis that has been conducted, the results of the study indicate that there is a significant positive relationship between reading skills and narrative writing skills in elementary school students. The average obtained for reading skills was $54.65 \%$ while for writing skills was $55.14 \%$. It can be concluded that reading and writing skills have a very close relationship, the more and better at reading, the better the written work. Based on the results of the analysis in this study, it is expected that students have good reading skills because reading is very influential on their writing skills. This research can also be used as a suggestion for teachers to motivate and pay attention to their students in reading and writing skills and as a reference for other researchers, because the results of this study were obtained from an analysis of 10 accredited journals and according to the variables taken.

Keywords: Reading Skills, Narrative Writing Skills

\section{PENDAHULUAN}

Pembelajaran bahasa Indonesia di Sekolah Dasar memiliki tujuan meningkatkan kemampuan siswa berkomunikasi secara efektif, baik lisan maupun tertulis 
(Ikhwanuddin, 2013). Ruang lingkup pembelajaran bahasa Indonesia mencakup empat aspek keterampilan berbahasa yaitu mendengarkan, berbicara, membaca, dan menulis (Astuti \& Mustadi, 2014). Empat aspek keterampilan berbahasa saling berkaitan satu sama lain, untuk mendapatkan empat aspek tersebut harus melalui proses yang urut, dimulai dari kegiatan menyimak, kemudian berbicara, dilanjutkan belajar membaca dan menuliskannya. Keterampilan menulis menjadi salah satu hal yang harus diajarkan kepada siswa. Di dalam proses keterampilan menulis ini sangat membutuhkan perhatian dari guru dan pihak pengajar, karena keterampilan menulis merupakan salah satu pembelajaran bahasa yang cukup kompleks.

Secara kultural masyarakat Indonesia belum memiliki budaya literasi membaca yang tinggi, hasil penelitian Programme for International Student Assesment (PISSA) menjelaskan bahwa posisi membaca siswa Indonesia di urutan ke 57 dari 65 negara yang diteliti. Data statistic UNESCO tahun 2012 juga menyebutkan indeks minat baca di Indonesia mencapai 0,001 artinya setiap 1.000 penduduk, hanya ada satu orang yang memiliki minat baca (Sari, 2020). Membaca adalah proses hubungan antara pembaca dan teks bacaan artinya suatu proses yang dilakukan dan digunakan oleh pembaca untuk memperoleh pesan (informasi) yang disampaikan oleh penulis melalui kata-kata atau bahasa tulis (Utami, 2018). Membaca adalah kegiatan yang sangat penting dalam dunia pendidikan yang kemudian dilanjutkan dengan kegiatan menulis.

Menulis adalah suatu aktivitas komunikasi bahasa yang menggunakan tulisan sebagai mediumnya (Bukhari, 2010). Menulis adalah sebuah proses, yaitu proses penuangan gagasan atau ide ke dalam bahasa tulis yang dalam praktik proses menulis diwujudkan dalam beberapa tahapan yang merupakan satu sistem yang lebih utuh (Nafiah, 2017). Hal ini sejalan dengan pendapat yang di kemukakan oleh Mirnawati yaitu writing is an activity of expressing feeling in written language in order to entertain, convey, explain, or tell something to someone (Mirnawati, 2019).

Memiliki keterampilan menulis juga memiliki manfaat yang sangat banyak. Menurut Akhadiah ada beberapa manfaat menulis diantaranya (Sobari, 2012):

“1) menulis dapat mengenali kemampuan dan potensi diri dan mengetahui sampai mana pengetahuan yang dimiliki dalam suatu topik; 2) menulis dapat mengembangkan berbagai gagasan; 3) dengan menulis lebih banyak menyerap, mencari, serta menguasai informasi sehubungan dengan topik yang sedang ditulis; 
4) menulis dapat mengkomunikasikan gagasan secara sistematis dan mengungkapkannya secara tersurat; 5) dengan menulis dapat menilai diri sendiri secara obyektif; 6) menulis dapat memecahkan permasalahan yaitu dengan menganalisanyasecara tersurat dalam konteks yang konkret; 7) menulis mendorong kita untuk belajar lebih aktif. 8) Dengan menulis akan membiasakan diri berpikir secara kritis".

Keterampilan membaca dan menulis adalah kegiatan yang saling berkaitan, keterampilan membaca berpengaruh terhadap keterampilan menulis, keterampilan menulis membutuhkan pengetahuan dan ide-ide yang akan dituangkan melalui tulisan sedangkan pengetahuan dan ide-ide diperoleh dari kegiatan membaca (Febrina, 2017). Kemampuan menulis yang baik tidak dapat diperoleh tanpa kemampuan membaca yang baik, karena dengan memiliki kemampuan membaca yang baik seseorang akan mendapatkan informasi yang lebih luas, pengalaman yang didapatkan pun lebih banyak sehingga kosakata yang dimiliki oleh pembaca akan lebih beragam.

Membaca adalah salah satu aktivitas belajar yang efektif untuk mendapatkan ilmu dan pengetahuan. Hal ini berarti membaca merupakan proses berpikir untuk memahami isi teks bacaan (Pratiwi et al., 2018). Membaca adalah salah satu kegiatan yang tidak bisa dipisahkan dalam dunia pendidikan, karena kegiatan membaca merupakan suatu proses transformasi ilmu melalui cara melihat dan memahami isi yang tertulis didalam sebuah buku pengetahuan maupun buku pelajaran (Nugraha et al., 2018). Sejalan dengan pendapat milik Tarigan dalam Kuanaben mengatakan bahwa membaca merupakan suatu keterampilan yang dilakukan serta dipergunakan oleh pembaca untuk memperoleh pesan, yang hendak disampaikan oleh penulis melalui bahasa tulis (Kuanaben, 2016).

Membaca juga memiliki manfaat yang banyak, menurut Rahim dalam Novrizta keterampilan membaca selain bermanfaat untuk menambah pengetahuan juga dapat memperbanyak perbendaharaan kata bagi si pembaca, banyaknya kosa kata yang dikuasai akan mempengaruhi kelancaran dalam menulis. Selain itu, membaca penting dilakukan untuk mengasah kemampuan intelektual seseorang dengan mempelajari estetika suatu tulisan, memelajari bagaimana agar tulisan itu dapat dipahami baik oleh penulis itu sendiri maupun orang lain, dan belajar bagaimana mengembangkan ide menjadi sesuatu yang bernilai lebih (Novrizta, 2019). Proses dan kegiatan membaca harus memiliki makna dan 
tujuan sehingga siswa akan memiliki motivasi untuk selalu melakukan kegiatan membaca. Kebanyakan anak perlu mendapatkan dukungan untuk selalu membaca.

Banyak faktor yang menyebabkan siswa masih rendah dalam keterampilan membaca yaitu siswa kurang gemar dalam keterampilan membaca, terlepas dari kesadaran diri akan pentingnya membaca untuk meningkatkan pengetahuan. Faktor lainnya banyak media elektronik yang berisi tentang hiburan dan permainan sehingga membuat siswa malas dalam keterampilan membaca (Almana et al., 2019). Keterampilan membaca saling berkaitan dengan keterampilan menulis yang dimiliki oleh seseorang. Siswa yang memiliki literasi membaca yang bagus juga akan mampu untuk menuliskan kalimat yang tertata, karena perbendaharaan kata yang dimilikinya lebih banyak daripada siswa yang tidak memiliki keterampilan membaca, siswa juga akan lebih mampu untuk menuliskan ide kreatif yang dimilikinya.

Ada beberapa permasalahan dalam keterampilan menulis sebab dari kurangnya keterampilan membaca, yaitu siswa menjadi kesulitan dalam mengeluarkan ide-idenya, siswa tidak memahami dengan baik tentang tata bahasa Indonesia yang baik dan benar dan juga karena perbendaharaan kata siswa yang sedikit menjadikan tulisannya menjadi kurang efektif (Martavia et al., 2016). Rendahnya keterampilan membaca yang dimiliki siswa ini juga berpengaruh terhadap wawasan dan penetahuan siswa, karena pada dasarnya wawasan dan pengetahuan sangat dibutuhkan dalam kegiatan menulis.

Masih banyak siswa Sekolah Dasar yang belum menyukai kegiatan menulis ini, entah dikarenakan merasa tidak memiliki bakat dalam menulis atau kebingungan tidak tahu apa yang hendak ditulis. Padahal kegiatan menulis memiliki banyak manfaat, diantaranya: (1) Dengan menulis maka potensi dan kemampuan diri siswa dapat dieksplorasi, dan (2) Dengan menulis siswa dapat melatih kemampuan dalam mengembangkan berbagai ide atau gagasan (Setiawan \& Mirnawati, 2017). Masalah yang sering terjadi dalam menulis adalah siswa merasa kesulitan untuk menuangkan ide yang dimiliki ke dalam kata-kata yang kemudian menjadi kalimat dan membentuk sebuah paragraf untuk dapat dibaca, siswa juga masih belum menguasai topik atau tema yang diberikan.

Menulis dan membaca adalah kegiatan yang saling berkaitan. Kegiatan menulis perlu dibiasakan dan dilatih sejak kecil, sehingga kreatifitas yang dimiliki oleh anak bisa 
tersalurkan dengan baik. Agar memiliki pengetahuan yang luas untuk ditulis perlu adanya kegiatan membaca, sehingga anak memiliki perbendaharaan kata yang cukup dan dapat menuangkan idenya dengan pemilihan kata yang tepat.

Tujuan penelitian ini yaitu untuk mengetahui apakah ada hubungan yang signifikan antara keterampilan membaca dengan keterampilan menulis pada siswa sekolah dasar.

\section{METODE PENELITIAN}

Jenis penelitian yang digunakan adalah penelitian kualitatif dengan menggunakan metode studi literatur. Sugiyono menjelaskan bahwa "studi literatur berkaitan dengan kajian teoritis dan referensi lain yang berkaitan dengan nilai, budaya dan norma yang berkembang pada situasi sosial yang diteliti" (Sugiyono, 2019). Penelitian ini menggunakan sumber data sekunder. Pengumpulan data yang didapatkan dalam penelitian ini dilakukan dengan cara mencari jurnal dan buku yang relevan sesuai dengan judul penelitian. Dari pencarian jurnal di internet (google scholar) didapatkan beberapa jurnal yang dipilih karena memiliki hasil penelitian sesuai dengan kriteria yang dibutuhkan dalam penelitian ini yaitu data keterampilan membaca siswa, data keterampilan menulis siswa, serta hubungan antara keterampilan membaca dan keterampilan menulis pada siswa sekolah dasar. Hasil data dari beberapa jurnal tersebut selanjutnya akan dianalisis menggunakan metode analisis korelasi untuk mengetahui seberapa erat hubungan antara variabel keterampilan membaca dengan variabel keterampilan menulis.

\section{HASIL DAN PEMBAHASAN}

Hasil penelitian yang relevan dalam penelitian studi literatur ini adalah sebagai berikut:

1. Nugraha dan Bintoro dengan judul "Hubungan Minat Membaca Dan Kemampuan Memahami Wacana Dengan Keterampilan Menulis Narasi” (Nugraha et al., 2018).

2. Novrizta dengan judul "Hubungan Antara Minta Membaca Dengan Keterampilan Menulis Karangan Narasi Siswa Sekolah Dasar" (Novrizta, 2019).

3. Pratiwi, dkk. dengan judul "Hubungan Antara Minat Membaca Dengan Keterampilan Menulis Cerita Pendek Siswa Kelas V SD Gugus VIII Mengwi Tahun Ajaran 2017/2018" (Pratiwi et al., 2018).

4. Arifah dengan judul "Hubungan Berpikir Kritis dan Membaca Pemahaman Dengan Kemampuan Menulis Argumentasi” (Arifa, 2018). 
5. Resnani dan Agustina dengan judul "Hubungan antara Kebiasaan Membaca dengan Hasil Belajar Bahasa Indonesia Siswa Kelas V Sekolah Dasar Negeri 69 Kota Bengkulu"(Resnani \& Agustina, 2014).

6. Kuanaben dengan judul "Hubungan Minat Membaca dengan Kemampuan Menulis Karangan pada Siswa Kelas V SDN Jarakan Kecamatan Sewon Kabupaten Bantul" (Kuanaben, 2016).

7. Saminodengan judul "Hubungan Berpikir Kreatif dan Kemampuan Membaca Pemahaman dengan Kemampuan Menulis Cerpen Siswa Kelas V Sekolah Dasar Strada Bhakti Nusa" (Samino, 2018).

8. Nurazizah dengan judul "Hubungan Intensitas Membaca dengan Keterampilan Menulis Narasi Siswa Kelas IV SD Gugus II Pengasih Kulon Progo” (Nurazizah, 2016).

9. Sari dengan judul "Hubungan Literasi Baca Tulis dan Minat Membaca dengan Hasil Belajar Bahasa Indonesia” (Sari, 2020).

10. Zulaikha dengan judul "Korelasi Kemampuan Membaca Pemahaman dengan Menulis Karangan Narasi” (Zulaikha, 2014).

Berdasarkan data hasil jurnal yang telah dipilih dalam penelitian ini, maka data yang telah didapatkan diolah kembali dengan merangkum hasil penelitian yang relevan. Selanjutnya data dianalisis secara deskriptif kuantitatif dan kualitatif.

Tabel 1. Tabel Hasil Analisis Keterampilan Membaca dengan Keterampilan Menulis Siswa Sekolah Dasar

\begin{tabular}{|c|c|c|c|c|c|}
\hline \multirow[t]{2}{*}{ No. } & \multirow[t]{2}{*}{ Judul } & \multirow[t]{2}{*}{ Peneliti } & \multicolumn{3}{|c|}{ Hasil } \\
\hline & & & $\begin{array}{c}\text { Membaca } \\
(\%)\end{array}$ & $\begin{array}{c}\text { Menulis } \\
(\%)\end{array}$ & Hubungan \\
\hline 1. & $\begin{array}{lr}\text { Hubungan } & \text { minat } \\
\text { membaca } & \text { dan } \\
\text { kemampuan } & \text { memahami } \\
\text { wacana } & \text { dengan } \\
\text { keterampilan } & \text { menulis } \\
\text { narasi. } & \end{array}$ & $\begin{array}{l}\text { Anggi Purwa } \\
\text { Nugraha, } \\
\text { Zulela MS, } \\
\text { Totok Bintoro. } \\
\text { (Nugraha et al., } \\
\text { 2018) }\end{array}$ & 36,5 & 46,7 & $\begin{array}{lr}\text { Minat } & \text { membaca } \\
\text { memberikan } & \text { pengaruh } \\
\text { positif } & \text { terhadap } \\
\text { keterampilan } & \text { menulis } \\
\text { narasi sebesar } & 37,3 \%\end{array}$ \\
\hline 2. & $\begin{array}{l}\text { Hubungan antara minta } \\
\text { membaca dengan } \\
\text { keterampilan menulis } \\
\text { karangan narasi siswa } \\
\text { Sekolah Dasar. }\end{array}$ & $\begin{array}{l}\text { Devi Novrizta. } \\
\text { (Novrizta, } \\
2019 \text { ) }\end{array}$ & 50 & 45,45 & $\begin{array}{l}\text { Diketahui bahwa } \\
\text { terdapat hubungan yang } \\
\text { positif sebesar } 63,8 \% \\
\text { anatara minat membaca } \\
\text { dan keterampilan } \\
\text { menulis. }\end{array}$ \\
\hline 3. & $\begin{array}{l}\text { Hubungan antara minat } \\
\text { membaca dengan } \\
\text { keterampilan menulis } \\
\text { cerita pendek siswa } \\
\text { kelas V SD Gugus VIII } \\
\text { Mengwi tahun ajaran } \\
2017 / 2018 \text {. }\end{array}$ & $\begin{array}{lr}\text { Dewa } & \text { Ayu } \\
\text { Putri } & \text { Pratiwi, } \\
\text { M.G Rini } \\
\text { Kristiantari, Ni } \\
\text { Nym. Ganing. } \\
\text { (Pratiwi et al., } \\
\text { 2018) }\end{array}$ & 74,89 & 65,98 & $\begin{array}{lr}\text { Hasil } & \text { analisis } \\
\text { menunjukkan terdapat } \\
\text { hubungan } \\
\text { signifikan antara minat } \\
\text { membaca } \\
\text { keteampilan menulis } \\
\text { pada taraf signifikan 5\% } \\
\text { diperoleh nilai Rxy } \\
\text { hitung }=0,480 .\end{array}$ \\
\hline
\end{tabular}




\begin{tabular}{|c|c|c|c|c|c|}
\hline \multirow[t]{2}{*}{ No. } & \multirow[t]{2}{*}{ Judul } & \multirow[t]{2}{*}{ Peneliti } & \multicolumn{3}{|c|}{ Hasil } \\
\hline & & & $\begin{array}{c}\text { Membaca } \\
(\%)\end{array}$ & $\begin{array}{l}\text { Menulis } \\
(\%)\end{array}$ & Hubungan \\
\hline 4. & $\begin{array}{lr}\text { Hubungan } & \text { berpikir } \\
\text { kritis dan } & \text { membaca } \\
\text { pemahaman } & \text { dengan } \\
\text { kemampuan } & \text { menulis } \\
\text { argumentasi. } & \end{array}$ & $\begin{array}{l}\text { Tutus } \\
\text { Arifah. } \\
\text { 2018) }\end{array}$ & 51,53 & 18,7 & $\begin{array}{lr}\text { Terdapat } & \text { hubungan } \\
\text { positif antara } & \text { berpikir } \\
\text { kritis dan } & \text { membaca } \\
\text { pemahaman } & \text { dengan } \\
\text { kemampuan } & \text { menulis } \\
\text { sebesar } 31,24 \% \text {. }\end{array}$ \\
\hline 5. & $\begin{array}{l}\text { Hubungan antara } \\
\text { kebiasaan membaca } \\
\text { dengan hasil belajar } \\
\text { bahasa Indonesia siswa } \\
\text { kelas V Sekolah Dasar }\end{array}$ & $\begin{array}{l}\text { Resnani dan } \\
\text { Refni Agustina. } \\
\text { (Resnani \& } \\
\text { Agustina, } \\
\text { 2014) }\end{array}$ & 38,46 & 76,92 & $\begin{array}{lr}\text { Terdapat hubungan yang } \\
\text { sifnifikan } & \text { antara } \\
\text { membaca dan } & \text { menulis } \\
\text { sebesar } 63,8 \% & \end{array}$ \\
\hline & $\begin{array}{lll}\text { Negeri } 69 & \text { Kota } \\
\text { Bengkulu. } & \end{array}$ & & & & \\
\hline 6. & $\begin{array}{lr}\text { Hubungan } & \text { minat } \\
\text { membaca } & \text { dengan } \\
\text { kemampuan menulis } & \text { karangan pada siswa } \\
\text { kelas V SDN Jarakan } \\
\text { Kecamatan Sewon } \\
\text { Kabupaten Bantul. }\end{array}$ & $\begin{array}{l}\text { Yublina } \\
\text { Kuanaben } \\
\text { (Kuanaben, } \\
\text { 2016) }\end{array}$ & 68 & 60 & $\begin{array}{l}\text { Berdasarkan hasil } \\
\text { penelitian minat } \\
\text { membaca berpengaruh } \\
\text { secara positif terhadap } \\
\text { menulis karanngan } \\
\text { sebesar } 9,9 \% \text {. }\end{array}$ \\
\hline 7. & $\begin{array}{l}\text { Hubungan berpikir } \\
\text { kreatif dan kemampuan } \\
\text { membaca pemahaman } \\
\text { dengan kemampuan } \\
\text { menulis cerpen siswa } \\
\text { kelas V Sekolah Dasar } \\
\text { Strada Bhakti Nusa. }\end{array}$ & $\begin{array}{l}\text { Francine Afanti } \\
\text { Samino. } \\
\text { (Samino, 2018) }\end{array}$ & 30 & 35 & \begin{tabular}{lr}
\multicolumn{2}{l}{ Terdapat hubungan yang } \\
positif & antara \\
kemampuan & membaca \\
pemahaman & dengan \\
kemampuan & menulis \\
cerpen sebesar & $12,89 \%$.
\end{tabular} \\
\hline 8. & $\begin{array}{l}\text { Hubungan intensitas } \\
\text { membaca dengan } \\
\text { keterampilan menulis } \\
\text { narasi siswa kelas IV } \\
\text { SD Gugus II Pengasih } \\
\text { Kulon Progo. }\end{array}$ & $\begin{array}{l}\text { Khikma } \\
\text { Fitriani Nur } \\
\text { Azizah. } \\
\text { (Nurazizah, } \\
\text { 2016) }\end{array}$ & 55,38 & 60 & $\begin{array}{lr}\text { Hasil } & \text { penelitian } \\
\text { menunjukkan adanya } \\
\text { hubungan yang positif } \\
\text { dan signifikan anatara } \\
\text { intensitas membaca } \\
\text { dengan keterampilan } \\
\text { menulis narasi sebesar } \\
61,7 \% \text {. }\end{array}$ \\
\hline 9. & $\begin{array}{l}\text { Hubungan literasi baca } \\
\text { tulis dan minat } \\
\text { membaca dengan hasil } \\
\text { belajar } \\
\text { Indonesia. }\end{array}$ & $\begin{array}{lr}\text { Putu } & \text { Ayu } \\
\text { Purnama } & \text { Sari. } \\
\text { (Sari, 2020) }\end{array}$ & 79,74 & 76,6 & $\begin{array}{l}\text { Terdapat hubungan yang } \\
\text { positif dan signifikan } \\
\text { antara keterampilan } \\
\text { membaca dan menulis } \\
\text { sebesar } 9 \% \text {. }\end{array}$ \\
\hline 10. & $\begin{array}{lr}\text { Korelasi } & \text { kemampuan } \\
\text { membaca } & \text { pemahaman } \\
\text { dengan } & \text { menulis } \\
\text { karangan narasi. }\end{array}$ & $\begin{array}{l}\text { Dwi Zulaikha. } \\
\text { Kaswari, } \\
\text { Maridjo AH. } \\
\text { (Zulaikha, } \\
\text { 2014) }\end{array}$ & 62,09 & 66,05 & $\begin{array}{l}\text { Terdapat korelasi antara } \\
\text { kemampuan membaca } \\
\text { pemahaman dengan } \\
\text { menulis karangan narasi } \\
\text { pada pembelajaran } \\
\text { bahasa Indonesia sebesar } \\
67 \% \text {. }\end{array}$ \\
\hline & & $\begin{array}{r}\text { Total } \\
\text { Rata-rata }\end{array}$ & $\begin{array}{c}549,59 \\
54,65\end{array}$ & $\begin{array}{l}551,4 \\
55,14\end{array}$ & \\
\hline
\end{tabular}


Berdasarkan hasil analisis data yang relevan di atas, keterampilan membaca dengan keterampilan menulis memiliki hubungan yang positif atau signifikan. Rata-rata yang diperoleh untuk keterampilan membaca siswa adalah 54,65\% sedangkan rata-rata untuk keterampilan menulis siswa sebesar 55,14\%. Hal ini menunjukkan bahwa keterampilan membaca dengan keterampilan menulis saling berkaitan erat. Siswa yang rajin membaca akan lebih mudah dalam kegiatan menulis, karena memiliki perbendaharaan kata yang mencukupi, pemilihan kosa kata pun lebih baik sehingga ide yang dimiliki dapat ditulis dengan mudah. Hal ini karena dalam kegiatan membaca terdapat dampak yang baik bagi perkembangan intelektual atau kemampuan kognitif siswa seperti membaca, menulis dan berhitung.

Membaca menjadi salah satu pilihan untuk dapat mengembangkan ide sesuai dengan tujuan yang ingin dicapai. Ide tulisan tidak akan datang tiba-tiba tanpa memiliki pengetahuan dan wawasan yang luas, oleh karena itu memperbanyak membaca akan memudahkan untuk bisa mengembangkan sebuah ide. Semakin banyak pengetahuan yang dimiliki maka seseorang akan lebih terampil dalam menulisnya. Memperbanyak membaca juga dapat meningkatkan kecerdasan, serta meningkatkan daya kreatifitas dan imajinasi. Hal tersebut sejalan dengan yang dikemukakan oleh Suparno dan Mohamad Yunus (Nurazizah, 2016) kualitas pengalaman membaca akan sangat mempengaruhi kesuksesannya dalam menulis. Artinya, semakin banyak dan baik dalam membaca maka hasil tulisannya akan semakin baik, seperti pemilihan kata dan struktur penulisan yang lebih rapi, memperbanyak jumlah kosa kata untuk dipahami, dan pola pikir akan lebih terbuka.

\section{KESIMPULAN DAN SARAN}

\section{Simpulan}

Berdasarkan data hasil penelitian yang dilakukan secara studi literatur, didapatkan kesimpulan untuk menjawab rumusan masalah terkait hubungan keterampilan membaca dan keterampilan menulis narasi siswa sekolah dasar yang diperoleh dengan menggunakan studi literatur yaitu, terdapat hubungan yang positif atau signifikan antara keterampilan membaca dengan keterampilan menulis. Analisa dari 10 jurnal yang relevan pun menyatakan bahwa terdapat hubungan positif antara keterampilan membaca dan keterampilan menulis siswa. Hal ini terjadi karena semakin tinggi keterampilan 
membaca yang dimiliki oleh siswa akan memiliki pengaruh terhadap keterampilan menulis siswa karena dengan membaca siswa dapat menambah wawasan, pengetahuan, kosakata yang dimiliki siswa akan bertambah, dan siswa bisa melatih diri untuk menulis dengan baik. Dengan demikian maka hendaknya guru dan orang tua dapat mengupayakan peningkatan intensitas keterampilan membaca.

\section{Saran}

Berdasarkan hasil penelitian dan kesimpulan yang sudah dijabarkan,maka dapat dikemukakan beberapa saran terkait hasil penelitian ini,sebagai berikut:

1. Bagi Siswa

Memiliki keterampilan membaca sangat diperlukan dalam berbagai kegiatan, membaca juga dapat dibiasakan sejak dini. Keterampilan membaca sangat berkaitan dengan keterampilan menulis. Semakin tinggi kemampuan membaca siswa maka semakin terlatih pula keterampilan menulisnya. Siswa disarankan agar dapat meningkatkan keterampilan membaca dengan baik sehingga dapat memiliki keterampilan menulis secara maksimal.

\section{Bagi Guru}

Guru diharapkan dapat memotivasi siswa dalam keterampilan membaca dan menulis, karena dengan memiliki keterampilan membaca dan menulis yang baik secara tidak langsung akan berpengaruh pada kualitas tulisan yang akan dibuat oleh siswa. Guru juga dapat membuat proses pembelajaran yang dapat meningkatkan keterampilan membaca dan menulis siswa.

\section{Bagi Peneliti Lain}

Peneliti lain dapat menggunakan artikel ini sebagai rujukan tambahan dalam penelitiannya karena hasil penelitian ini didapat dari hasil analisis 10 jurnal lain yang relevan dengan variabel yang ada dan sudah terakreditasi. Hasil dari 10 jurnal tersebut adalah terdapat hubungan positif yang signifikan antara keterampilan membaca dan keterampilan menulis siswa sekolah dasar. 


\section{DAFTAR RUJUKAN}

Almana, E. S., Santa, \& Anwar, W. S. (2019). Pengaruh Kegemaran Membaca Terhadap Keterampilan Menulis Narasi. Riset Pedagogik, 3(1), 80-92. https://jurnal.uns.ac.id/jdc/article/view/34076/22647

Arifa, T. R. (2018). Hubungan Berpikir Kritis Dan Membaca Pemahaman Dengan Kemampuan Menulis Argumentasi. Muallimuna: Jurnal Madrasah Ibtidaiyah, 4(1), 50. https://doi.org/10.31602/muallimuna.v4i1.1427

Astuti, Y. W., \& Mustadi, A. (2014). Pengaruh Penggunaan Media Film Animasi Terhadap Keterampilan Menulis Karangan Narasi Siswa Kelas V SD. Jurnal Prima Edukasia, 2(2), 250-262. https://doi.org/10.21831/jpe.v2i2.2723

Bukhari. (2010). Keterampilan Berbahasa Membaca dan Menulis. PeNA.

Febrina, L. (2017). Pe1 Padangngaruh Minat Baca Cerpen Terhadap Keterampilan Menulis Cerpen Siswa Kelas X MAN. MENARA Ilmu, XI(74), 113-124.

Ikhwanuddin, M. A. (2013). Penerapan Metode Mind Mapping Untuk Meningkatkan Keterampilan Menulis Karangan Narasi Pada Siswa Kelas IV A SDN Wonosari O2 Semarang [Universitas Negeri Semarang]. https://lib.unnes.ac.id/17678/1/1401409135.pdf

Kuanaben, Y. (2016). Hubungan Minat Membaca Dengan Kemampuan Menulis Karangan Pada Siswa Kelas V SDN Jarakan Kecamatan Sewon Kabupaten Bantul. Jurnal Pendidika Guru Sekolah Dasar, 5(8), 737-745.

Martavia, R. F., Thahar, H. E., \& Asri, Y. (2016). Hubungan Minat Baca dengan Keterampilan Menulis Narasi Ekspositoris Siswa Kelas VII SMP Negeri 11 Padang. Jurnal Pendidikan Bahasa Dan Sastra Indonesia, 5(2), 363-369.

Mirnawati, L. B. (2019). Keefektifan Model Pembelajaran Inovatif Dengan Menggunakan Mind Mapping Dalam Pembelajaran Menulis Narasi Siswa SD. Jurnal Belajar Bahasa, 4(1), 82-92.

Nafiah, S. A. (2017). Model- Model Pembelajaran Bahasa Indonesia SD/MI. Ar Ruzz Media.

Novrizta, D. (2019). Hubungan Antara Minat Membaca Dengan Keterampilan Menulis Karangan Narasi Siswa Sekolah Dasar. Jurnal Review Pendidikan Dan Pengajaran, 104-124.

Nugraha, A. P., MS, Z., \& Bintoro, T. (2018). Hubungan Minat Membaca dan Kemampuan Memahami Wacana dengan Keterampilan Menulis Narasi. Indonesian Journal of Primary Education, 2(1), 19-29. https://doi.org/10.17509/ijpe.v2i1.11647 
Nurazizah, K. F. (2016). Hubungan Intensitas Membaca dengan Keterampilan Menulis Narasi Siswa Kelas IV SD Gugus II Pengasih Kulon Progo. Jurnal Pendidikan Guru Sekolah Dasar, 12, 163-171.

Pratiwi, D. A. P., Kristiantari, M. . R., \& Ganing, N. N. (2018). Hubungan Antara Minat Membaca Dengan Keterampilan Menulis Cerita Pendek Siswa Kelas V Sd Gugus Vii Mengwi Tahun Ajaran 2017/2018. Journal for Lesson and Learning Studies, l(1), 43-51. https://doi.org/10.23887/jlls.v1i1.14626

Resnani, \& Agustina, R. (2014). Hubungan Antara Kebiasaan Membaca Dengan Hasil Belajar Bahasa Indonesia Kelas V Sekolah Dasar Negeri 69 Kota Bengkulu. Journal of Chemical Information and Modeling, 7(2), 1689-1699. https://doi.org/10.1017/CBO9781107415324.004

Samino, F. A. (2018). Hubungan Berpikir Kreatif Dan Kemampuan Membaca PEmahaman Dengan Kemampuan Menulis Cerpen Siswa Kelas V Sekolah Dasar Strada Bhakti Nusa. Jurnal Pendidikan Dasar, 9(1), 98-108. https://doi.org/10.21009/JPD.091.08

Sari, P. A. P. (2020). Hubungan Literasi Baca Tulis Dan Minat Membaca Dengan Hasil Belajar Bahasa Indonesia. Journal for Lesson and Learning Studies, 3(1), 141152.

Setiawan, F., \& Mirnawati, L. B. (2017). Upaya Meningkatkan Keterampilan Menulis Karangan Siswa Kelas IV Sekolah Dasar Dengan Menggunakan Media Gambar Berseri. Prosiding Seminar Nasional Publikasi Hasil-Hasil Penelitian Dan Pengabdian Masyarakat, September, 134-140. http://repository.upy.ac.id/589/1/Dokumen 1_ hlm. Sampul\%2C Abstrak\%2C Persetujuan...hingga Daftar.pdf

Sobari, T. (2012). Penerapan Teknik Siklus Belajar Dalam Pembelajaran Menulis Laporan Ilmiah Berbasis Vokasional. Sematik, 1(1), 17-41. https://doi.org/10.22460/semantik.vXiX.XXX

Sugiyono. (2019). Metode Penelitian Kuantitatif, Kualitatif, dan R\&D - MPKK (Edisi 2 Ce). Alfabeta, CV Bandung.

Utami, R. (2018). Panduan Terampil Membaca (Cet. 2). CV. Teguh Karya.

Zulaikha, D. (2014). Korelasi Kemampuan Membaca Pemahaman Dengan Menulis Karangan Narasi. Artikel Penelitian Prodi Pendidikan Guru Sekolah Dsar Universitas Tanjungpura. 
Volume 4, Nomor 2, Agustus 2020 